\title{
History of pediatric critical care medicine
}

\author{
Daniel L. Levin ${ }^{\mathrm{a} *}$, John J. Downes ${ }^{\mathrm{b}}$ and I. David Todres ${ }^{\mathrm{c}}$ \\ ${ }^{a}$ Departments of Pediatrics and Anesthesia, Children's Hospital at Dartmouth, Geisel School of Medicine, \\ Lebanon, NH, USA \\ ${ }^{\mathrm{b}}$ Department of Anesthesiology and Critical Care Medicine, The Children's Hospital of Philadelphia, University \\ of Pennsylvania Perelman School of Medicine, Philadelphia, PA, USA \\ ${ }^{\mathrm{c}}$ Department of Anesthesia and Critical Care Medicine, Massachusetts General Hospital, Harvard Medical \\ School, Boston, MA, USA
}

Received 12 July 2013

Revised 15 January 2014

Accepted 8 February 2014

\begin{abstract}
.
OBJECTIVES: to review and cite important individuals and events in the development of pediatric critical care medicine (PCCM). DATA SOURCES: A MEDLINE search was performed looking for citations of the history of PCCM. This yielded 85 citations of which 46 were obtained. Thirty nine of the 85 were rejected as inappropriate either by title (e.g., pediatric emergency medicine) or because they were in a foreign language only. After review of the 46, 21 were included in this review and the others rejected as inappropriate. Textbooks of PCCM were reviewed for chapters on the history of PCCM and four were included. Forty-eight personal communications were made to individuals and four to organizations to elicit and verify information. One speech is referenced and from these sources, a total of 37 additional textbooks, monographs and chapters and 47 journal manuscripts and reference sites were found and included.
\end{abstract}

SELECTION AND EXTRACTION: Materials pertinent to the specific disciplines, individuals and events in the development of $\mathrm{CCM}$ (Critical care medicine) and PCCM were included in this review.

CONCLUSIONS: PCCM owes a great debt to the expertise in anesthesiology, neonatology, pediatric cardiology, pediatric general and cardiovascular surgery and nursing for its evolution. The modern PCCM unit and service is more the result of the need to treat and organize care for critically ill and injured patients than to any developments in technology.

Keywords: history, pediatrics, critical care, pediatric critical care, ventilation, poliomyelitis

\section{Introduction}

The modern pediatric intensive care unit (PICU) and the physicians who staff it on a full time basis, pediatric intensivists, have professional roots reaching

*Corresponding author: Daniel L. Levin, Departments of Pediatrics and Anesthesia, Children's Hospital at Dartmouth, Geisel School of Medicine, One Medical Center Drive, Lebanon, New Hampshire, 03756, USA. Tel.: +1 603650 5454; E-mail: Daniel.L.Levin@ hitchcock.org. back to Biblical times [1-4]. This history intimately involves development of a modern understanding of anatomy and physiology. This understanding fostered the evolution of resuscitation and assisted ventilation, to treat major organ failure and the organizational efforts necessary to effectively implement these. We refer the interested reader to previous works to review the evolution of knowledge in anatomy, physiology, and the early development of resuscitation and assisted ventilation in relation to the modern PICU [2]. 


\subsection{Definitions}

An important principle of PCCM is centralization of resources and expertise. With highly trained individuals and sophisticated technology in specialized physical spaces.

\subsubsection{A Pediatric Intensive Care Unit}

In the 1983, the American Academy of Pediatrics (AAP) and Society of Critical Care Medicine (SCCM) Joint Guidelines for Pediatric Intensive Care Units [5] \{updated 1993 [6] and 2007 [7]\} the committee defined a PICU as, "... a hospital unit which provides treatment to children with a wide variety of illnesses of lifethreatening nature including children with highly unstable conditions and those requiring sophisticated medical and surgical treatment." Randolph et al. [8] have expanded this definition, stating, "A PICU is a separate physical facility or unit specifically designated for the treatment of pediatric patients who, because of respiratory failure, shock, trauma, or other life-threatening conditions, require intensive, comprehensive observations and care."

\subsubsection{Pediatric Intensivist}

Randolph et al. [8] define a pediatric intensivist (in the United States) as "... any one of the following: (a) a pediatrician with subspecialty training in PCCM and subspecialty certification from the American Board of Pediatrics (ABP); (b) a pediatric anesthesiologist with special competency in critical care with subspecialty certification from the American Board of Anesthesiology; (c) a pediatric surgeon with special competency in critical care with subspecialty certification from the American Board of Surgery; (d) a physician (as above) eligible for subspecialty certification by their respective board." Similar requirements for training exist or are in development elsewhere in the world.

\section{Material and Methods}

The experience of the authors represents a total of more than 120 yr. devoted to PCCM and we draw heavily on our experience. In addition, a MEDLINE search was performed for citations on the history of PCCM. This yielded 85 citations of which 46 were deemed pertinent. The 39 that were rejected were deemed not relevant. Four textbooks of PCCM with informative chapters on history were included. Fortyeight personal communications with individuals were made to elicit and verify information. One speech is cited. The World Federation of Pediatric Intensive and Critical Care Societies (WFPICCS), AAP, the Pediatric Critical Care Sub-board of the ABP, and SCCM were also contacted. Review of the manuscripts, textbook chapters and the personal communications, resulted in an additional 37 textbooks, monographs and chapters and 47 manuscripts and reference sites being reviewed for preparation of this paper. Information shedding light on the individuals, places and events that led to the development of PCCM was included. Despite this extensive effort, this paper of necessity presents an incomplete historical review. Information on the evolution of PCCM in the developing world and in countries such as China, South Korea, Japan and Israel proved to be minimal or only presented in a foreign language.

\section{Results}

\subsection{The Contributions of Specific Disciplines}

PCCM developed initially through the efforts of pediatric anesthesiologists, as well as pediatric general and cardiac surgeons, and neonatologists. In fact, most of the original PICUs were founded by pediatric anesthesiologists (Table 1), [1,2,9-18]. This occurred because before discrete intensive care units evolved, critically ill children often received close monitoring, intensive nursing care and pulmonary support in the post-anesthetic recovery room. There the anesthesiologists were the attending physicians with the requisite knowledge and skills for this effort. In addition to those PICUs noted in table 1 , there were probably others, which were not well documented.

\subsubsection{Pediatric General and Cardiac Surgery}

Dr. William E. Ladd (1880-1967) at Children's Hospital of Boston (CHB) pioneered of many techniques to operate on non-cardiac congenital malformations and his protégé Dr. Robert Gross, first successfully operated on patent ductus arteriosus in 1937 and later on other congenital cardiac lesions. Dr. C. Crawfoord in Sweden and Dr. Gross in Boston, both successfully repaired a coarctation of the aorta in 1945. Drs. Alfred Blalock (surgeon) and Helen Taussig (cardiologist) with Mr. Vivien Thomas (laboratory assistant) at Johns Hopkins also in 1945, created the subclavian-to-pulmonary artery shunt for tetralogy of Fallot. Dr. John Gibbon at Jefferson Medical College Hospital in Philadelphia performed the first successful open-heart surgery using cardiopulmonary 
Table 1

Some early pediatric intensive care units and programs*

\begin{tabular}{|c|c|c|c|}
\hline Year & Institution/Location & Medical Director(s) & Director(s) Specialty*: \\
\hline 1955 & $\begin{array}{l}\text { Children's Hospital } \\
\text { Goteburg, Sweden }\end{array}$ & G. Haglund & Ped Anesth. \\
\hline 1961 & $\begin{array}{l}\text { St. Goran's Children's } \\
\text { Hospital, Stockholm, Sweden }\end{array}$ & H. Feychtin & Ped Anesth. \\
\hline 1961 & $\begin{array}{l}\text { Great Ormond Street Children's } \\
\text { Hospital, London, England }\end{array}$ & W. Glover & Ped Anesth. \\
\hline 1963 & $\begin{array}{l}\text { Hospital St. Vincent de Paul, } \\
\text { Paris, France }\end{array}$ & $\begin{array}{l}\text { J. B. Joly } \\
\text { G. Huault }\end{array}$ & $\begin{array}{l}\text { Neonatology } \\
\text { Neonatology }\end{array}$ \\
\hline 1963 & $\begin{array}{l}\text { Royal Children's Hospital, } \\
\text { Melbourne, Australia }\end{array}$ & $\begin{array}{l}\text { I. H. McDonald } \\
\text { J. Stocks }\end{array}$ & $\begin{array}{l}\text { Ped Anesth. } \\
\text { Ped Anesth. }\end{array}$ \\
\hline 1964 & $\begin{array}{l}\text { Alden Hey Children's Hospital } \\
\text { Liverpool, England }\end{array}$ & G. J. Rees & Ped Anesth. \\
\hline 1967 & $\begin{array}{l}\text { Children's Hospital of Philadelphia, } \\
\text { Philadelphia, Pennsylvania }\end{array}$ & J. J. Downes & Ped Anesth. \\
\hline $1968^{* * * *}$ & $\begin{array}{l}\text { Children's Hospital District of } \\
* * * * \text { Columbia, Washington, DC }\end{array}$ & C. Berlin & Ped. \\
\hline 1968 & $\begin{array}{l}\text { Children's Hospital Calvo } \\
\text { Mackenna, Santiago de Chile }\end{array}$ & E. Bancalari & Ped. \\
\hline 1969 & $\begin{array}{l}\text { Children's Hospital of Pittsburg, } \\
\text { Pittsburg, Pennsylvania }\end{array}$ & S. Kampschulte & Ped Anesth. \\
\hline 1969 & $\begin{array}{l}\text { Yale-New Haven Medical Center, } \\
\text { New Haven, Connecticut }\end{array}$ & $\begin{array}{l}\text { J. Gilman } \\
\text { N. Talner }\end{array}$ & $\begin{array}{l}\text { Ped Anesth } \\
\text { Ped Cardiol. }\end{array}$ \\
\hline 1971 & $\begin{array}{l}\text { Massachusetts General Hospital, } \\
\text { Boston, Massachusetts }\end{array}$ & $\begin{array}{l}\text { D. Shannon } \\
\text { I. D. Todres }\end{array}$ & $\begin{array}{l}\text { Ped Pulm. } \\
\text { Ped. \& } \\
\text { Ped Anesth. }\end{array}$ \\
\hline 1971 & $\begin{array}{l}\text { Hospital for Sick Children, } \\
\text { Toronto, Canada }\end{array}$ & A. Conn & Ped Anesth. \\
\hline 1971 & $\begin{array}{l}\text { Long Island Jewish Hospital, } \\
\text { New York }\end{array}$ & B. Holtzmann & Ped Pulm. \\
\hline 1971 & $\begin{array}{l}\text { Montifiore Hospital, } \\
\text { New York }\end{array}$ & R. Kravath & Ped Pulm. \\
\hline 1972 & $\begin{array}{l}\text { Sainte Justine Hospital, } \\
\text { Montreal, Canada }\end{array}$ & $\begin{array}{l}\text { M. Weber } \\
\text { A. Lamarre }\end{array}$ & $\begin{array}{l}\text { Ped. } \\
\text { Ped Pulm. }\end{array}$ \\
\hline 1972 & $\begin{array}{l}\text { Children's Hospital "Dr. R. Guiterrez", } \\
\text { Buenos Aires, Argentina }\end{array}$ & J. Sasbon & Ped. \\
\hline 1972 & $\begin{array}{l}\text { Children's Hospital "Pedro Elizade", } \\
\text { Buenos Aires, Argentina }\end{array}$ & C. Bonno & Ped. \\
\hline 1972 & $\begin{array}{l}\text { Hospital for Sick Children, } \\
\text { Edinburgh, Scotland }\end{array}$ & H. Simpson & Neonatology \\
\hline 1974 & $\begin{array}{l}\text { Red Cross Children's War Memorial } \\
\text { Hospital, Cape Town, South Africa }\end{array}$ & M. Klein & Ped Pulm. \\
\hline 1975 & Private Hospital, Uruguay & M. Gajer & Ped. \\
\hline 1975 & $\begin{array}{l}\text { Children's National Hospital } \\
\text { Medical Center, Washington, DC }\end{array}$ & $\begin{array}{l}\text { P. R. Holbrook } \\
\text { A. Fields }\end{array}$ & $\begin{array}{l}\text { Ped. } \\
\text { Ped. }\end{array}$ \\
\hline 1975 & $\begin{array}{l}\text { Children's Medical Center, } \\
\text { Dallas, Texas }\end{array}$ & $\begin{array}{l}\text { D. Levin } \\
\text { F. Morriss }\end{array}$ & $\begin{array}{l}\text { Ped. } \\
\text { Ped. \& } \\
\text { Ped Anesth. }\end{array}$ \\
\hline 1976 & $\begin{array}{l}\text { Hospital Infantil La Paz, } \\
\text { Madrid, Spain }\end{array}$ & F. Ruza & Ped. \\
\hline 1977 & $\begin{array}{l}\text { Johns Hopkins Medical Center, } \\
\text { Baltimore, Maryland }\end{array}$ & $\begin{array}{l}\text { M. C. Rogers } \\
\text { S. Nugent }\end{array}$ & $\begin{array}{l}\text { Ped. \& } \\
\text { Ped Anesth. } \\
\text { Ped. }\end{array}$ \\
\hline 1977 & $\begin{array}{l}\text { Sheba Medical Center, } \\
\text { Israel }\end{array}$ & F. Barzilay & Ped. \\
\hline 1977 & $\begin{array}{l}\text { Children's Hospital of San Diego, } \\
\text { San Diego, California }\end{array}$ & B. Peterson & $\begin{array}{l}\text { Ped. \& } \\
\text { Pedi Anesth. }\end{array}$ \\
\hline 1977 & $\begin{array}{l}\text { Hospital de Clinicas, } \\
\text { Sao Paulo, Brazil }\end{array}$ & A. Wong & Ped. \\
\hline
\end{tabular}


Table 1. Some early pediatric intensive care units and programs* (Continued)

\begin{tabular}{|c|c|c|c|}
\hline Year & Institution/Location & Medical Director(s) & Director(s) Specialty** \\
\hline 1978 & $\begin{array}{l}\text { Sophia's Children's Hospital, } \\
\text { Rotterdam, Netherlands }\end{array}$ & $\begin{array}{l}\text { E. van der Voort } \\
\text { H. van Vught }\end{array}$ & $\begin{array}{l}\text { Ped. } \\
\text { Ped. }\end{array}$ \\
\hline 1978 & $\begin{array}{l}\text { Children's Hospital of Los Angeles, } \\
\text { Los Angeles, California }\end{array}$ & E. Arcinue & Ped. \\
\hline 1979 & $\begin{array}{l}\text { University of Minnesota Hospital, } \\
\text { Minneapolis, Minnesota }\end{array}$ & B. Fuhrman & Ped. \\
\hline 1980 & $\begin{array}{l}\text { Moffett Hospital, } \\
\text { San Francisco, California }\end{array}$ & G. Gregory & Ped Anesth. \\
\hline 1980 & $\begin{array}{l}\text { Children's Hospital Boston, } \\
\text { Boston, Massachusetts }\end{array}$ & R. Crone & $\begin{array}{l}\text { Peds \& } \\
\text { Ped Anesth. }\end{array}$ \\
\hline \multicolumn{4}{|c|}{$\begin{array}{l}\text { Adapted from references. [1,2,9-18]. } \\
* \text { This is not intended to be an absolutely complete list. It is primarily comprised of units well documented in the literature. } \\
* \text { * Primary specialties (not all inclusive) } \\
\text { *** Although conceptual development of unit started in 1965, Dr. Berlin states the first year of operation of the present I.C.U. was in } 1969 \text { (opened } \\
\text { December 1968). }\end{array}$} \\
\hline
\end{tabular}

bypass for closure of an atrial septal defect in 1953 [2]. These advances in pediatric surgery created the need for excellent and often complex postoperative care.

Dr. C. Everett Koop who had completed surgical residency at the University of Pennsylvania in 1945 then trained in Boston with Dr. Gross for $6 \mathrm{mo}$. He returned to The University of Pennsylvania and the Children's Hospital of Philadelphia (CHOP) in 1946. With the help of Dr. Leonard Bachman, director of anesthesiology, and the nursing staff, Dr. Koop developed the first neonatal surgical intensive care unit in 1962. Dr. Bachman and his young associate, John J. Downes, subsequently set up the first PICU in the hospital in 1967.

\subsubsection{Neonatology}

Pediatric critical care owes a great debt to neonatal pediatricians $[1,2,19]$. In the $1880 \mathrm{~s}$ and $1890 \mathrm{~s}$ special care nurseries were developed in Paris. The first and most prominent of these was established by obstetricians Etienne Tarnier and his young associate Pierre Budin at the Hospital la Charitre with a unit that had a full time dedicated nursing staff, incubators, gavage feeding of breast milk, and aseptic practices resulting in a reduction of hospital infant mortality from $197 / 1000$ live births to $46 / 1000$ live births. Their work presaged the development of modern neonatal intensive care in the 20th century. In 1914, the first premature infant center in the United States was opened at Michael Reese Hospital in Chicago by Dr. Julius Hess (1876-1955). Canadian pediatrician, Dr. Alfred Hart in 1928, performed exchange transfusions involving peripheral artery cannulation. In 1932, Drs. Louis Diamond, Kenneth Blackfan, and James Batey at CHB determined the pathophysiology of hemolytic anemia and jaundice of erythroblastosis fetalis, and in1948 described exchange transfusions using a feeding tube inserted in the umbilical vein.

In the 1950s and 1960s, Dr. Geoffrey Dawes at the Nuffield Institute for Medical Research at Oxford University, using fetal and newborn lambs, described the fetal and transitional circulation of mammalian newborns. In the late 1950's, Columbia University's obstetrical anesthesiologist Virginia Apgar, who had devised the Apgar score for assessing birth asphyxia, recruited Dr. L. Stanley James to develop animal and human investigaton of the transitional pulmonary cardiovascular adaptation during labor, delivery, and the post-natal period. Dr. James and his team at Columbia, and Dr. Abraham Rudolph, a South African pediatric cardiologist, and his team at Albert Einstein Medical Center in New York City, performed extensive studies in fetal lambs, Rhesus Monkeys and term and pre-term human newborns that defined the human cardiopulmonary adaptation to delivery and post-natal life. They also determined the biochemical factors and time course of birth asphyxia and recovery. Concurrently, similar studies were being conducted by groups in London and elsewhere in Europe.

Dr. Clement Smith at Boston Lying-In Hospital published his textbook of neonatal physiology in 1945, the first such text in English. In 1959, a research fellow at Harvard, Dr. Mary Ellen Avery (with mentor Dr. Jere Mead) discovered deficiency of alveolar 
surfactant in lungs of newborns dying from respiratory distress syndrome (RDS). This discovery led to a better understanding of neonatal pulmonary disorders, and eventually to the intra-tracheal instillation of surfactant in newborn pre-term infants to prevent or mitigate the severity of respiratory distress syndrome.

\subsubsection{Pediatric Cardiology}

As previously indicated, the successful cardiac operations by Robert Gross and the vision of Dr. Taussig in devising a method to treat "blue babies", led to infants and children who survived surgery and needed postoperative care. Advances in technology, especially for imaging, have allowed clinicians to "see" into living patients with astounding accuracy. Increased understanding of anatomy and physiology has led to improved surgical care for children with very complex cardiopulmonary problems. Perhaps ironically, recent developments in cardiac catheterization and interventional radiology have enabled clinician to treat many lesions without surgery, improving outcomes without need for open-heart surgery and potentially difficult postoperative intensive care. This concept was actually introduced in 1968 by Dr. William Rashkind with the introduction of the balloon atrial septostomy for infants with transposition of the great arteries. Burgeoning growth of techniques, both interventional and surgical, has resulted in many centers creating specific cardiac intensive care units often run by pediatric cardiac intensivists. Cognitive impairment in some infants with complex lesions and/or chromosomal abnormalities, and the occasional development of chronic respiratory failure with dependence on mechanical ventilation for months or years are two of the occasional major sequele of this highly successful endeavor in correcting or palliating complex cardiovascular lesions. The value of PCCM for these cardiac patients and other critically ill children has been well documented by Dr. Jacqueline Noonan [20]. She notes, "Much success of the surgery can be attributed to a group of pediatric intensivists, pediatric intensive care units, improved ventilatory support, and trained respiratory therapists.

\subsubsection{Early Use of Mechanical Ventilation in Neonates and Children}

Although isolated case reports of occasional success with mechanically assisted ventilation had appeared in the medical literature in the early 20th century, no series of carefully observed infants had been published until 1959. In that year, Drs. P. M. Smythe (pediatrician) and Arthur Bull (anesthesiologist) reported the first real success in mechanical ventilation of a series of neonates with respiratory failure. These infants, with neonatal tetanus, were paralyzed with curare and ventilated for 4 to 14 days using tracheotomy and a modified Radcliff adult ventilator [21]. Up until that time, infants were rarely given ventilator support for more than a few hours using adult ventilators or with manual ventilation. There were no specifically designed pediatric ventilators, nor small volume blood gas analysis available. Dr. Smythe had to overcome these obstacles by innovation. On July 13, 1957, he performed a tracheostomy and began intermittent positive-pressure ventilation on a Bantu neonate with tetanus from the tribal areas at Groote Schuur Hospital, with the assistance of anesthesiologist Bull. This was truly a landmark event in the evolution of PCCM. There are two interesting points to be made about their work. First, although considered a success story in that it was a first time infants survived long-term (up to several weeks) positive-pressure mechanical ventilation, the first seven of nine patients died. Eventually their survival rate reached $80 \%$ to $90 \%$. Second, they commented that, "No praise can be too high for the nursing staff, who were all student nurses and without any special training."

In 1963-1964 in Toronto, Drs. Paul Swyer, Maria Delivoria-Papadopoulos and Henry Levison were the first to successfully treat a series of premature infants with RDS with positive-pressure mechanical ventilation and supportive care [22]. They emphasized the importance of a full-time team, including dedicated nurses and therapists as well as physicians. In 1968, Dr. George Gregory and colleagues at the University of California at San Francisco demonstrated greatly improved survival with continuous positive airway pressure (CPAP) without assisted ventilation and with positive end-expiratory pressure (PEEP) added to mechanical ventilation regimen [23]. However, as always, progress in treating a disorder leads to unforeseen complications and new disorders. Successful treatment of RDS led to some survivors with chronic lung disease, retinopathy of prematurity, and hypoxic brain injury. This observation is still relevant today: Pediatric intensive care allows successful treatment of disorders previously considered hopeless, but also results in small numbers of infants and children with long-term problems that require study, clinical commitment and long-term advocacy for them and their families. 


\subsection{Poliomyelitis and Creation of the First ICU'S}

Poliomyelitis epidemics occurred worldwide in the early 20th century but seemed especially severe in Western Europe and North America. There was no treatment and until the late 1920's with no effective life support for those victims with respiratory failure. Fortunately, the confluence of great scientific and clinical minds, and the organizational efforts of physicians, nurses, and therapists addressing the needs of polio patients rapidly led the creation of dedicated polio respiratory care units for patients of all ages. In 1929, Philip Drinker, an engineer, with pediatricians Louis Shaw, and Charles F. McKhann at the CHB published their experience with an electrically powered negative-pressure body enclosing mechanical ventilator, later termed the "iron lung" [24,25].

Polio outbreaks occurred in the summer months worldwide in the 1930's and 1940's. The polio epidemics of the early 1950's were very severe in Los Angeles and Copenhagen. In 1952, Dr. H. C. Lassen, Chief Epidemiologist, Blegdam Hospital, Copenhagen, describes treating 2772 patients with polio. Of these, 316 were in respiratory failure and initially received assisted ventilation with "iron lungs" in a large respiratory care unit. During that summer, they had a census of as many as 70 patients in respiratory failure in that unit. Unfortunately the mortality of patients supported by an iron lung ventilator was nearly $90 \%$, with the cause of death frequently being unrecognized upper airway obstruction. When the census of patients in respiratory failure exceeded the available number of iron lung ventilators, Bjorn Ibsen, the Chief of Anesthesiology at the hospital, with the help of his medical staff and nurse anesthetists, performed tracheal intubation and then tracheostomy along with manual positivepressure ventilation with $50 \%$ oxygen, and tracheal suctioning. This care was carried out in 200 patients with respiratory failure. To provide continuous manual ventilation on a $24 \mathrm{~h}$ basis, Ibsen recruited, trained and employed 200 nursing students and aides and 200 medical students at a time, each working 8-h shifts to provide manual ventilation as well as 27 technicians per day to care for the patients [26-28]. The mortality in patients receiving this care decreased from $90 \%$ to $40 \%$ [27,28].

Another change in strategy was that patients from outlying areas were being sent in ambulances without sufficient attendants and airway care and arrived moribund. Lasen and Ibsen started to send teams ("retrieval teams") in ambulances out to pick up the patients in the countryside, with marked improvement in status on arrival. They also started passing stomach tubes early on for nutrition, and the rubber-cuffed tracheostomy tubes were replaced with a silver cannula that caused less tracheal mucosal damage. Even with all these improvements Dr. Ibsen concludes, "Naturally we ran into a lot of complications" [28]. Drs. Ibsen and Lassen, also received help from other bright people who were focusing their efforts on treating polio. The clinical biochemist, Dr. Poul Astrup, developed a micro method to measure capillary arterialized $\mathrm{pH}$ and $\mathrm{PCO}_{2}$ in infants, children and adults. C. G. Engstrom, a Swedish anesthesiologist, designed and clinically tested the first modern volume-preset positive-pressure mechanical ventilator. This spectacular and thrilling story resulted in a cohort of patients in respiratory failure in a single geographical area being care for by full-time physicians, nurses, and technicians, the first modern intensive care unit. Although these units tended to disband after the summer-fall polio season, they led to creation of full-time respiratory care units at the Oxford University and elsewhere in Europe and North America in the 1950's.

\subsubsection{The First PICU}

In 1955, Dr. Goran Haglund at the Children's Hospital of Goteberg, Sweden [13] developed the first PICU which he called a Pediatric Emergency Ward. The patient who inspired Dr. Haglund to organize the unit was a 4-year-old boy who was operated on in 1951 for a ruptured appendix. Postoperatively, he lapsed into a coma and the surgeon declared they had done all they could and he would die of "bacteriotoxic coma". The anesthesiologist offered to help and the boy was intubated, given manual positive-pressure respiration with generous oxygen, tracheostomized, and given a large blood transfusion. After about $8 \mathrm{~h}$, the bowels started to move, and $4 \mathrm{~h}$ later he was out of coma. After $20 \mathrm{~h}$, he had spontaneous respiration and had been successfully treated for respiratory insufficiency and shock.

The new unit has 7 acute care beds, 6 full-time nurses and 15 nursing assistants, with 24-h coverage. In the first $5 \mathrm{yr}$, the team treated 1183 infants and children, with a mortality rate of $13.6 \%$. Haglund goes on to state, "But what we did was something else. It was the application of the basic physiology to clinical practice. Our main purpose was not to heal any disease; it was to forestall the death of the patient. The idea was - and is - to gain time, time so that the special medical and/or surgical therapy can have 
desired effects." [13]. Haglund was also careful to point out that, "There are few jobs more exciting, demanding, and taxing than emergency nursing. Our nurses and nurse assistants are tremendous. They must be!" [13]. Unfortunately, Dr. Haglund did not publish his experience, except for a brief meeting abstract, until a decade later [13].

In 1958 at Baltimore City Hospital, Dr. Peter Safar established a multidisciplinary ICU for adult and pediatric medical and surgical patients [29]. Dr. Barrie Fairley developed a similar unit only for adults at the Toronto General Hospital in 1960. These were the first true intensive care units in North America. As has been shown, the dissemination of the knowledge and skills that anesthesiologists had developed in the operating room to postoperative recovery rooms, surgical and medical wards, and eventually to geographically defined units, permitted improved treatment of patients with a variety of disorders, only some of which required surgical intervention. Among the diseases treated were, as indicated previously, polio in the early 1930 s to mid-1950s and acute respiratory failure due to a variety of pulmonary, neurologic and myopathic conditions from the late 1950s through the 1960s. In addition, Reye syndrome in the 1970s and 1980s often caused respiratory failure [2]. These disorders, along with developments in neonatology, pediatric general and cardiac surgery, and pediatric cardiology created a demand for improved services for unstable infants and children. The events paralleled those in the world of adult critical care.

\subsubsection{The Central Role of Nursing}

Although many sources emphasize the role of advanced technology in the creation of adult, neonatal, and pediatric critical care [2,14] skilled nursing care was even more important in this evolving process. Porter [30] as well as others, reminds us of the vital role of nursing in triage and organization of care for patients by degree of illness. Long before the organizational efforts of the 20th century, Florence Nightingale (1820-1920) organized nursing services and a clean environment at the British military hospital at Skutari, Turkey in 1854 during the Crimean War. Although the care consisted mostly of hygiene and nutrition, the mortality rate dropped from $40 \%$ to $2 \%$ [31]. Nightingale provided the definition of nursing as "helping the patient to live" [31]. These efforts were continued in the United States by Dorothea Dix (1802-1887) and Clara Barton (1821-1912), the "Angel of the Battlefield" during the
American Civil War. Barton also brought the Red Cross to America in 1882.

As the complexity of medical and surgical care evolved in the late 19th and early 20th century the need for cohorting sick patients and providing skilled nursing care became apparent, especially for the premature newborn and for the victims of poliomyelitis as cited above. Then as now the recovery of the critically ill pediatric or adult patient depended on the skilled nurse at the bedside who was trained to utilize the life support and monitoring equipment at hand, but remained focused on the stability and comfort of the person in the bed.

The subspecialty of pediatric critical care nursing evolved in the 1970s and 1980s. Many nurses serving in adult and pediatric intensive care units became members of the SCCM from its inception in 1972. In the mid-1990s, pediatric critical care nurses founded their own society and established a peer reviewed journal. Also in the 1990s, advanced practice nurses and nurse practitioners began to specialize in pediatric critical care. They began and continue to function as important critical care team members to augment both physician and nursing care as well as conduct clinical research. Numerous informative articles and chapters point to the central importance of nursing in creating and enabling intensive care units and critical care nursing to develop $[1,2,13,15,21,22,30]$.

\subsubsection{The Role of Pediatric Anesthesiologists and Pediatricians in Founding PCCM}

As we have seen, geographically defined PICUs, directed by specific medical and nursing personnel, emerged in the 1950s and 1960s, and their development gathered momentum in the 1970s. Most, but not all, early PICUs were founded by pediatric anesthesiologists (Table 1). An important, early physiciandirected multidisciplinary PICU in North America was established at Children's Hospital of Philadelphia (CHOP) in January, 1967, as an outgrowth of a hospital-wide respiratory intensive care service [2,3]. The unit consisted of an open ward of six beds equipped with bedside electronic monitoring and respiratory support capabilities and an intensive care chemistry laboratory, manned $24 \mathrm{~h}$ per day located next to the unit. The nurses were assigned full-time to the unit, and most had previously served in the recovery room, the infant ICU, or the cardiac surgery postoperative ward. Dr. John Downes was the medical director and worked closely with two other anesthesiologists, Dr. Leonard Bachman, Chief of Anesthesiology, 
and Dr. Charles Richards, and a pediatric allergist/ pulmonologist, Dr. David Wood. Four pediatric anesthesiology/critical care fellows provided $24 \mathrm{~h}$ in unit service. Dr. C. Everett Koop (Chief of Surgery), Dr. William Rashkind (the father of interventional pediatric cardiology), Dr. John Waldhausen (one of the nation's few full-time pediatric cardiac surgeons and a creative thinker), and Dr. Sylvan Stool (a pioneer in pediatric otolaryngology) and other staff and residents provided close collaboration in patient care, education and clinical research.

In 1971, at the Hospital for Sick Children in Toronto, Dr. Alan Conn resigned as director of the Department of Anesthesiology to become director of a new multidisciplinary 20-bed PICU, by the far the largest and most sophisticated unit in North America. Establishment of this unit and a critical care service culminated a decade of efforts by Dr. Conn and his associates. During the prior decade Dr. Conn and his colleagues had cohorted critically ill infants and children in a sequestered area of the post-anesthesia care facility where they had developed considerable expertise in critical care. This new state-of-the-art PICU was the forerunner of units developed in major pediatric centers throughout North America throughout the 1970s and beyond.

Also in 1971, Dr. David Todres, an anesthesiologist and pediatrician, and Dr. Daniel Shannon, a pediatric pulmonologist, founded a 16-bed multidisciplinary unit for pediatric patients of all ages at the Massachusetts General Hospital [1,2]. The Units in Toronto and Boston established vibrant training programs in critical care medicine and conducted clinical research. Among their numerous accomplishments, Dr. Conn became a noted authority on the management of near-drowning victims, and Dr. Todres and Dr. Downes pioneered long-term mechanical ventilation for children at home with chronic respiratory failure. These early PICUs and their training programs had a favorable impact on mortality and morbidity rates - particularly those associated with acute respiratory failure - and led to development of similar units and programs in most major pediatric centers in North America and Western Europe during the 1970s and early 1980s.

Some of the early PICUs were directed by pediatricians. In 1966, Dr. Max Klein joined Drs. H. de V. Heese and Vincent Harrison in a two-bed neonatal research unit at the Groote Shuur Hospital in Cape Town. Over the course of the next $2 \mathrm{yr}$ and more, their research resulted in many significant papers, not the least of which was, "The Significance of
Grunting in Hyaline Membrane Disease" [32], demonstrating that oxygen tensions fell when infants were not allowed to grunt. This provided the rationale for the application of CPAP, an artificial grunt, to these patients. By 1969, at Red Cross War Memorial Children's Hospital, pediatric patients with respiratory failure (e.g., Guillain-Barre) were ventilated on the wards and deaths were common. There was no centralized facility for older children. Dr. Klein encouraged Dr. Malcolm Bowie (consultant) to start a six-bed ICU, or "high-care ward", originally in collaboration with the anesthesiology staff. After further training in South Africa and at the University of California San Francisco, in 1974, Dr. Klein returned to Cape Town where he combined the neonatal tetanus ward of Dr. Smythe and the six-bed ICU of Dr. Bowie into the first full-time PICU in South Africa. An important aspect of the effort was that, at the time, the hospital was racially segregated. It took Dr. Klein $25 \mathrm{yr}$ of persistent effort to create a non-segregated PICU [33].

The path for pediatricians providing care for the sickest patients on a full-time basis remained unclear for an extended period. Subsequent early leaders in the field each carved out their own path. Dr. Daniel Levin completed pediatric cardiology and neonatology fellowships to learn the care of sick children. However he found few Chairs of Pediatrics interested in hiring an "intensivist". Then in 1975 Drs. Levin and Frances Morriss (pediatrics and pediatric anesthesia), were recruited to Dallas by Dr. Theodore Votteler, Chief of Surgery (a former trainee of Dr. Koop), and Dr. Heinz Eichenwald, Chairman of Pediatrics, to start a PICU at Children's Medical Center of Dallas.

There were so few of this new breed of "intensivists" that many became directors upon completion of residency and fellowship. At the beginning, no one wanted to be responsible for pediatric intensive care [18]. Eventually more pediatricians decided to devote their careers to being members of a multidisciplinary team taking care of the sickest children in hospitals on a full-time basis. In 1975, the CHOP program started to accept PCCM trainees who were pediatricians without anesthesia residency.

In 1970, Dr. Peter Holbrook as a senior medical student at the University of Pennsylvania in 1969-1970 had a lengthy elective in the PICU at The Children's Hospital of Philadelphia and, based on that experience, decided on a career in PCCM. However, during his residency at Johns Hopkins, he was discouraged by prominent pediatricians and told by some that he 
needed to become an anesthesiologist. Dr. Peter Safar in Pittsburgh, however, welcomed him as a fellow in critical care medicine in a personalized program to prepare him for PCCM. Dr. Safar told him, "We've been waiting for you" [17]. In 1975, Dr. Holbrook and pediatrician Dr. Alan Fields, who also trained in Pittsburgh, were recruited to the Children's Hospital National Medical Center, as pediatricians in the Department of Anesthesia to run their PICU.

Dr. Bradley Peterson [34], after pediatric and neonatology training and an anesthesiology residency at Stanford University, became director of the new PICU at Children's Hospital of San Diego in 1977. Dr. Bradley Fuhrman, following pediatric cardiology and neonatology fellowships, started the first PICU at University of Minnesota Hospital in 1979 [35].

Dr. George Lister [36], after pediatric residency at Yale and a fellowship in cardioplmonary physiology at the University of California San Francisco (UCSF), in 1977 joined the staff at the UCSF Moffitt Hospital as an attending in their combined adult-pediatric ICU. Due to the director's illness, he quickly found himself the co-director of the unit [36]. He eventually returned to Yale as an attending in the PICU and subsequently the Chair of the Department of Pediatrics.

Dr. Mark Rogers, after completion of pediatric and anesthesiology residencies and pediatric cardiology fellowship at the Massachusetts General Hospital, in 1975 became director of their first PICU at Johns Hopkins Hospital [37]. Subsequently, in 1980 Dr. Rogers became Chair of the Department of Anesthesiology and Critical Care Medicine at Johns Hopkins, and chief editor of a major textbook of pediatric intensive care (Table 2).

\subsubsection{The Growth of PCCM}

The field of PCCM grew rapidly in the late 1970s and 1980s. During this period, Calvin [65] indicated there was a struggle for authority in adult units, with

Table 2

Textbooks in pediatric critical care medicine

\begin{tabular}{|c|c|c|c|}
\hline $\begin{array}{l}\text { Year First } \\
\text { Edition }\end{array}$ & Title & Editors & Reference \\
\hline 1971 & The Care of the Critically Ill Child & R. Jones, J. B. Owen-Thomas & {$[38]$} \\
\hline 1971 & Pediatric Intensive Care: Manual & K. Roberts, J. Edwards & [39] \\
\hline 1972 & $\begin{array}{l}\text { Nelson's, The Critically Ill Child: Diagnosis } \\
\text { and Medical Management }\end{array}$ & $\begin{array}{l}\text { J. Dickerman } \\
\text { J. Lucey }\end{array}$ & [40] \\
\hline 1979 & A Practical Guide to Pediatric Intensive Care & $\begin{array}{l}\text { D. Levin } \\
\text { F. Morriss } \\
\text { G. Moore }\end{array}$ & [41-44] \\
\hline 1980 & $\begin{array}{l}\text { Tratado de Cuidados Intensivos Pediatrucos } \\
\text { (Textbook of Pediatric Intensive Care) }\end{array}$ & F. J. Ruza & [45] \\
\hline 1984 & Nursing Care of the Critically Ill Child & M. F. Hazinski & {$[46]$} \\
\hline 1984 & Textbook of Critical Care & $\begin{array}{l}\text { W. K. Shoemaker } \\
\text { W. L. Thompson } \\
\text { P. R. Holbrook }\end{array}$ & [47] \\
\hline 1984 & Pediatric Intensive Care & E. Nussbaum & {$[48]$} \\
\hline 1985 & $\begin{array}{l}\text { Temeas em Terapia Intensiva (Issues } \\
\text { in Pediatric Intensive Care) }\end{array}$ & $\begin{array}{l}\text { J. Piva } \\
\text { P. Carvalho } \\
\text { P. Celiny Garcia }\end{array}$ & [49] \\
\hline 1985 & Critical Care Pediatrics & $\begin{array}{l}\text { S. Zimmerman } \\
\text { J. Gildea }\end{array}$ & {$[50]$} \\
\hline 1987 & Pediatric Intensive Care & J. P. Morray & {$[51]$} \\
\hline 1988 & Pediatric Intensive Care & M. C. Rogers & {$[52]$} \\
\hline 1992 & Pediatric Critical Care & $\begin{array}{l}\text { B. P. Fuhrman } \\
\text { J. J. Zimmerman }\end{array}$ & [53] \\
\hline 1993 & Textbook of Pediatric Critical Care & P. R. Holbrook & {$[54]$} \\
\hline 1994 & Urgences \& Soins Intensif Pediatriques & $\begin{array}{l}\text { J. Lacroix } \\
\text { M. Gauthier } \\
\text { F. Beaufils }\end{array}$ & {$[55]$} \\
\hline 1995 & $\begin{array}{l}\text { Critical Heart Disease in Infants } \\
\text { and Children }\end{array}$ & $\begin{array}{l}\text { D. G. Nichols } \\
\text { D. E. Cameron } \\
\text { W. J. Greeley }\end{array}$ & {$[56]$} \\
\hline
\end{tabular}


Table 2. Textbooks in pediatric critical care medicine (Continued)

\begin{tabular}{|c|c|c|c|}
\hline $\begin{array}{l}\text { Year First } \\
\text { Edition }\end{array}$ & Title & Editors & Reference \\
\hline & & $\begin{array}{l}\text { D. W. Lappe } \\
\text { R. M. Ungerleider } \\
\text { R. C. Wetzel }\end{array}$ & \\
\hline 1996 & $\begin{array}{l}\text { Critical Care of Infants } \\
\text { and Children }\end{array}$ & $\begin{array}{l}\text { I. D. Todres } \\
\text { J. H. Fugate }\end{array}$ & [57] \\
\hline 1996 & $\begin{array}{l}\text { Critical Care Nursing of Infants } \\
\text { and Children }\end{array}$ & $\begin{array}{l}\text { M. A. Curley } \\
\text { J. Bloedel-Smith } \\
\text { P. A. Moloney } \\
\text { Harmon }\end{array}$ & [58] \\
\hline 1997 & $\begin{array}{l}\text { Illustrated Textbook of Pediatric } \\
\text { Emergency \& Critical Care Procedures }\end{array}$ & $\begin{array}{l}\text { R. A. Dieckmann } \\
\text { D. H. Fiser } \\
\text { S. M. Selbst }\end{array}$ & [59] \\
\hline 1997 & Pediatric Intensive Care & N. S. Morton & [60] \\
\hline 2001 & $\begin{array}{l}\text { Manual de Cuidados Intensivos } \\
\text { Pediatricos }\end{array}$ & $\begin{array}{l}\text { J. Lopez-Herce } \\
\text { Cid } \\
\text { C. Calvo Rey } \\
\text { M. J. Lorente } \\
\text { Acosta } \\
\text { A. Baltodano } \\
\text { Aquero }\end{array}$ & [61] \\
\hline 2005 & Cuidudo Intensivo Pediatrico y Neonatal & $\begin{array}{l}\text { J. Forero } \\
\text { J. Alarcon } \\
\text { G. Cassalett }\end{array}$ & [62] \\
\hline 2006 & Pediatric Critical Care Medicine & $\begin{array}{l}\text { A. D. Slonim } \\
\text { M. M. Pollack }\end{array}$ & [63] \\
\hline 2007 & $\begin{array}{l}\text { Pediatric Critical Care Medicine: Basic } \\
\text { Science and Clinical Evidence }\end{array}$ & $\begin{array}{l}\text { D. S. Wheeler } \\
\text { H. R. Wong } \\
\text { T. P. Shanley }\end{array}$ & [64] \\
\hline
\end{tabular}

some clinicians trying to change the culture of intensive care from one in which each different service cared for its "part" of the patient to one in which a full-time critical care service was consistently available, and cared for the whole patient, with help of consulting specialties. Although this conflict was probably worse in units for adults, it was certainly a prominent issue in PICUs as well [17].

For PCCM to achieve its full potential it required:

(1) a national structure in which to meet and communicate

(2) acceptance and validation of pediatric critical care as a subspecialty

(3) formalized training requirements

(4) academic credibility with meaningful research

A small group of interested physicians met at the Society of Critical Care Medicine (SCCM) National Meeting in 1979 and decided to petition the SCCM to form a section of pediatrics. The society had no subsections, but the petition was successful, and the pediatric section with Dr. Holbrook as chair was formed in 1980 [2]. In 1983, a committee of the SCCM developed guidelines for PICUs [5] which have been regularly updated [6,7].

In 1981, Dr. James Orlowski, with the support of others, petitioned The AAP to form a section of Pediatric Critical Care or Intensive Care Medicine with the AAP. Although there was some controversy, the petition was successful and the section began in 1984 with Dr. Russell Raphaely as Chairman [66]. These organizations provided structure, places to meet, and opportunities to discuss common goals and concerns. These organizations then petitioned for recognition of PCCM fellowships and trained subspecialties in PCCM from the American College of Graduate Medical Education (ACGME) and ABP. Increasing international interest in pediatric intensive care was recognized with the first World Congress of Pediatric Intensive Care in Baltimore in 1992, and establishment of the WFPICCS in Paris in 1997 [18].

Legitimization of the subspecialty was achieved with establishment of a new Sub-board of Pediatric Critical Care Medicine of the ABP in 1985. The 
first certifying examination occurred in 1987 [66]. Certification provided clear guidelines for hospital credentialing of PCCM physicians [67]. In 1989, special requirements for training in PCCM were developed by the ACGME with formally accredited programs first recognized in 1990 [68]. The first subboard examination in 1987 certified 182 PCCM sub-specialists. By 2006, there were 1454 certified pediatric intensivists [66].

\subsubsection{Growth in Numbers of PICUs}

In 1979, Ross Planning Associates identified 150 PICUs of four or more beds, and another 42 were through to exist (total 192) [69]. Most were just special care nursing units only $40 \%$ had a pediatric intensivist available at all times. Forty percent of the units had fewer than seven beds and only one half had affiliated transport systems. By 1995, there were 306 general PICUs and in 2001 there were 349. Of these, $94 \%$ had a pediatric intensivist on staff. Pediatric ward beds decreased by $22.4 \%$ between 1980 and 1989 , by $10.8 \%$ between 1990 and 1994 , and by $15.7 \%$ between 1995 and 2000. During the same three time periods, PICU beds increased by $26.2 \%, 19.0 \%$ and $12.9 \%$, respectively [8].

\subsubsection{Growth in Training Programs and Education}

In 1983-1984 there were 32 PCCM training programs, and the ACGME accredited 28 of them in 1990. By 2008, there were 62 PCCM training programs [68]. The number of fellows enrolled in PCCM has increased by $41 \%$ in the decade 1997 to 2006. The percent of women fellows increased from $40 \%$ to $45 \%$ from 1997 to 2006 where it remained in 2011. Eighty-five percent of applicants in 2006 for subspecialty board certification intended to work exclusively as intensivists [68].

Education within the field has progressed rapidly. Educational programs were established at the annual SCCM, AAP, Pediatric Academic Societies (PAS), and American Thoracic Society (ATS) meetings.

These have been supplemented by a unique volunteer effort, started in 1987 by Dr. Hector James, a pediatric neurosurgeon from San Diego, and continued by Dr. Peter Holbrook in 1988, called the Pediatric Critical Care Colloquium (PCCC). The 20th colloquium was held in 2013. National and regional organizations around the world conduct many other specialty-specific meetings. There have been various textbooks in the field in many languages including texts specifically for PCC nurses (Table 2). Through the efforts of the editorial board of society's journal, Critical Care Medicine, and the WFPICCS, a new journal, Pediatric Critical Care Medicine, began in 2000, edited by Dr. Patrick Kochanek [70]. Academic credibility that results from meaningful scientific research has come slowly. In the early days, intensivists were mostly consumed by clinical and administrative responsibilities, but high-quality science, addressing a broad range of problems, has gradually emerged. Huge efforts and funds have done into clinical PCCM trials in attempts to improve outcomes. Initially these trials have failed to deliver clear beneficial results [14] such as the multi-institutional trials of liquid ventilation $[71,72]$, recombinant bacterial/permeability - increasing protein (rBPI 21) [73] and activated protein $\mathrm{C}$ [74]. This most likely results from the incredibly difficult task of performing large clinical trials on very sick children with a heterogeneous group of disorders.

In the early 1990s, the Pediatric Critical Care study group was formed and led by Dr. Gregory Stidham [14,75]. In 1998, Drs. Adrienne Randolph, Jacques Lacroix and Douglas Willson, initiated a clinical trials group to provide collaboration and oversight in conductance of three multi-center trials [76-78]. This group subsequently evolved into the Pediatric Acute Lung Injury and Sepsis Investigators Group (PALISI). By directly applying the already successful programmatic model of research developed by the Canadian Critical Care Trials Group (CCCTG) $[79,80]$ Pediatric Acute Lung Injury and Sepsis Investigators Group (PALISI) has grown and prospered through the voluntary collaboration of more than 70 North America member units [81]. This effort has resulted in many publications in high-quality journals, ongoing funded clinical trials and observational studies, and active new protocol development. The Virtual PICU was started in 2000, enabling Drs. Randall Wetzel of Children's Hospital of Los Angeles and Thomas Rice of The Children's Hospital of Wisconsin to create a massive database for research and quality control [14]. In Canada, the "Pediatric Interest Group" was created in the year 2000 within the CCCTG by Drs. Jacques Lacroix, James Hutchison, and Haresh Kirpalani, with the help of the Canadian Institutes of Health Research [82].

In April 2004, the National Institute for Child Health and Human Development established funding (renewed in 2009) for the first network supporting pediatric critical care research, the Collaborative Pediatric Critical Care Research Network (CPCCRN). 
Its purpose is "To initiate a multi-centered program designed to investigate the safety and efficacy of treatment and management strategies to care for critically ill children, as well as the pathophysiologic basis of critical illness and injury in childhood." [83]. In the first $5 \mathrm{yr}$, a number of landmark studies including observational studies on bereavement, opioid tolerance, and pertussis were initiated, as well as several interventional trials. The latter included a randomized controlled trial of immune prophylaxis and a study developing and testing a functional status outcomes scale. The NIH has also supported research in PCCM through the Pediatric Critical Care Scientist Development Program (PCCSDP), a K-12 research training program funded by the Eunice Kennedy Shriver National Institute of Child Health and Development to support the training of young physician scientists in pediatric critical care. PCCSDP entered its second project period In 2009, under the continuing direction of Dr. Michael Dean at University of Utah [84].

The growth of education and research in PCCM has coincided with better care for children. In addition to the examples of diseases such as polio, tetanus, and Reye Syndrome that fortunately disappeared but were stimuli for forming the subspecialty, the decrease in mortality from septic shock helps demonstrate continued improvements in patient outcomes. During the period from 1958 to 1966 , in patients less than $16 \mathrm{yr}$ of age at the University of Minnesota, mortality in septic shock was $95 \%$ but now is less than $10 \%$ [85].

Drs. Murray Pollack and Timothy Yeh established the basis for studying severity-adjusted mortality in pediatrics and demonstrated that patients do better when cared for by pediatric intensivists [86] Dr. Debra Fiser's group [87] has shown improvement in mortality associated with critical care in patients with a variety of respiratory diseases. Although many would attribute these improvements to technology and scientific advances, Dr. Yeh and others remind us that the presence of a full-time team and attention to basic principles rather than exotic high-technology improves outcomes [88]. This is echoed by Dr. Frank Shann, who has two rules of PCCM: Rule 1 is "the most important thing is to get the basics exactly right all of the time"; Rule 2 is "organizational issues are crucially important" [12]. In addition, Yeh as well as Ibsen [28] and Richard Orr have emphasized the important contributions of regionalization and the quality of PCCM transport teams in improving outcomes [89,90].

\subsubsection{The Cost of Success in PCCMs}

Everything comes at a cost. In the field of PCCM, as in many others, advances have lead to increased financial cost, survivors with chronic disease, medical errors, and occasional dehumanization of patients. The accurate estimates of the extraordinary but necessary financial costs of modern care of the critically ill child are difficult to assess, but in at least two publications, have been documented [91,92]. Because of the relatively small number of infants and children who require critical care compared with the total population, PCCM contributes only slightly to the overall national expenditures for health care.

Pediatric intensivists are aware and concerned about the increased population of chronic patients who have prolonged PICU stays, frequent readmissions, and need for intensive care at home or in the rare pediatric sub-acute facility. Most of these patients did not exist in the 1960s and early 1970s because they died. Although we return many very sick children to complete health, a small number, often with associated complex disorders survive but live with chronic neurological, respiratory, cardiac, or renal disease. These children and their families usually require extraordinary medical and social support and advocacy in order to thrive.

Over the years since PCCM began, pediatric intensivists have come to the realization that caring for critically ill children requires simultaneous gathering of information in two areas. One is the disease itself, which includes the symptoms, signs, investigations, and clinical management. The other is the context of illness, which is the patient's and family's concerns, expectations, feelings, and thoughts that are unique to each individual and family. An intensivist acts to bring about a positive good or benefit to the patient; however, experience in the PICU has shown that conflicts arise when presumption to save life (a good) requires interventions that may cause undue suffering. Ethical dilemmas are receiving increased attention [1] and hospital ethics committees have proven very helpful in educating the critical care team and aiding in resolution of these difficult issue.

The increasingly diverse patient population of the United States and elsewhere has presented pediatric intensivists with the need to understand and respect individual cultural differences. Care has become increasingly centered on the child and family, with recognition of the effects of personal spiritual/religious, cultural, and family values on the child's illness and recovery, and in coping with end of life [93]. One way clinicians 
have attempted to support patients and families is to include families as members of the team by having them present at rounds with their child [94]. This effort allows the family, and often the patient, to hear what the team has to say and to ask questions, both of which empower the family and build trust.

In many PICUs, chaplains have become an important part of the intensive care team, offering understanding, counsel and solace at the bedside and in team meetings with families. Addition of child psychiatrists and social workers to the PICU consulting team has helped families and children cope with severe and devastating effects of critical illness or injury.

Since the inception of PCCM, members of the team have experienced long hours of stressful work and occasional feelings of despair and frustration that their efforts are not making a difference. This can lead to emotional distress, and a sense of loss of fulfillment in their professional lives. Understanding of this problem by local medical and nursing leaders helps the team realize they are making an important difference through their efforts and dedication. Such understanding by team leaders and their support of other team members can help reduce burnout and enhance staff morale.

\subsection{Around the World}

We have alluded to the many contributions of people around the world to the evolution of PCCM, both through innovative treatment of specific diseases (e.g. polio [2,25-27] and tetanus [21]) and in organizing and creating PICUs (see Table 1), and education (see Table 2 [95]). What follows below illustrates some of the varied contributions from many places. This is not intended to be all inclusive.

\subsubsection{Canada}

As described above under Pediatric Anesthesiologists and PCCM, at the Hospital for Sick Children in Toronto, Dr. Alan Conn, Anesthetist-in-Chief, a pioneer in Canadian pediatric critical using the post-anesthesia recovery room, had the vision of developing a multidisciplinary PICU for medical and surgical patients. In 1971, he took the position of full-time director of a then state-of-the-art 20 bed critical care unit and initiated a flourishing clinical and research program. Dr. Conn was followed in 1981, by Dr. Geoffrey Barker, who continued to promote the unit as one of the leading PICUs in the world [96]. Dr. Barker had the vision of the need to bring together pediatric intensive care from many parts of the world. This lead to his founding directorship of the WFPICCS, which has done much to foster development of pediatric critical care in countries around the world, bringing vital critical care skills and experience to benefit of multiple countries. In Montreal, the first patient was mechanically ventilated outside the postoperatively recovery room in 1965, in what would later be named the PICU. The unit was first run by Dr. Paul Stanley, a pediatric cardiac surgeon A medical PICU was created in 1972 by a pediatrician, Dr. Michel Weber, and pulmonologists Dr. Andre Lamarre. The units were merged in 1982. Drs. Marie Gauthier, Jacquest Lacroix (Universite de Montreal) and John Gordon (McGill University) were very active in development and implementation in 1992, of a fellowship program in PCCM supervised by the Royal College of Physicians and Surgeons of Canada [82].

\subsubsection{South Africa}

As described above under Early Use of Mechanical Ventilation, in 1959, Dr. P. M. Smythe, a pediatrician working with Dr. Arthur Bull, an anesthesiogist a the Red Cross Children's War Memorial Hospital in Cape Town, South Africa, conceived a brilliant therapeutic plan to treat infants afflicted with neonatal tetanus from infected umbilical cord stumps [21]. At Red Cross Children's Hospital, a special unit for critically ill children opened in 1974 with full time intensivists. Dr. Max Klein with Drs. Louis Reynolds, Jan Vermeulen, Paul Roux, and later Andrew Argent assumed this role. Dr. Klein's commitment to psychosocial issues in the care of patients was exemplary. His vision went beyond the PICU. In an excellent home-care tracheostomy program of 60 to 70 children, he, with Nurse Jane Booth, were successful in ensuring care of these children despite dreadful home conditions. In talking with Dr. Todres about this program, he recalled his enthusiasm for the need to have these children nurtured away from the hospital, and his staff provided these children with visits outside the home including public gardens $[1,33,97]$.

\subsubsection{Japan}

In the 1960s, Dr. Seizo Iwai, Chief of Anesthesia at the National Children's Hospital in Tokyo, was the first Japanese physician to introduce long-term mechanical ventilation and arterial blood gas analysis of critically ill infants, fostering a tradition of anesthesiologists taking care of critically ill infants and children outside of the operating room. He was a strong 
force in developing a close relationship with other Asian countries and invited trainees from those countries to promote teaching and development of pediatric critical care in their homeland. His close working relationship with Drs. Conn and Barker in Toronto, Canada, paved the way for Dr. Katsuyuki Miyasaka to study in Torono with Dr. Conn and in Philadelphia with Dr. Downes. Dr. Miyasaka returned to Japan in 1977 and, in October 1994, opened the first geographically distinct PICU in Japan at the National Children's Hospital. He also helped to found the Japanese Society of Pediatric Intensive Care. He continues to foster the development of a new generation of pediatric intensivists as a hospital director and plays a major rule in facilitating this process [98].

\subsubsection{India}

Development of neonatal and pediatric critical care in India has been previously described in detail [99] NICUs (Neonatal intensive care units) in India were established in the 1960s, first at All India Institute, Delhi, and subsequently at teaching hospitals in other major cities. Today, almost all major cities in India have NICUs providing different levels of intensive care. The well-established NICUs provide care on a par with NICUs in the Western countries [100].

The first PICUs were established at major postgraduate centers (Delhi, Chennai, Chandigarh, Mumbai, and Lucknow) nearly two decades after development of NICUs [101]. A special interest group of the Indian Academy of Pediatrics (IAP) working in PICUs was formed in 1997, and the Section of Pediatric Instensive Care was formed in the Indian Society of Critical Care Medicine (ISCCM) in 1998 [102]. The Pediatric Critical Care Council (PCCC), a joint body of the Intensive Care chapter of the IAP and the Pediatric Section of the ISCCM [103] provides professional practice guidelines in pediatric critical care for the practitioners and hospitals. The section also has initiated fellowship training programs in recognized units [104]. Today, PCCM is the fastest growing pediatric subspecialty in India. Growth of PICUs had been mainly in the private sector, although major government teaching hospitals are also improving the PICUs in their hospitals.

Prompt access to the available services is critical for pediatric patients. A study at a Children's Hospital in Hyderabad, Andhra Pradesh, India has shown that patients travel long distances (up to $500 \mathrm{~km}$ ) to seek pediatric critical care, with survival inversely proportional to distance traveled [105]. To overcome these difficulties, a bold and innovative statewide patient transport program, The Emergency Management and Research Institute (EMRI), started in 2005 with a fleet of 70 ambulances deployed in the State of Andhra Pradesh [106]. The public-private collaborative organization has 2500 staff including EMTs, support staff, and associates, and a call center in the capital city of Hyderabad. A call, using number 108 from any phone in the state gives access to ambulance service even in remote parts of the state. After $5 \mathrm{yr}$, EMRI has a fleet of 652 ambulances, covers 23 districts, and attends to over 4500 emergency calls per day. The EMRI center is linked to 331 private and public hospitals throughout the state and because of its' success, the model is being adopted in other states of the country [107].

\subsubsection{Australia and New Zealand}

As in the United States and Canada, Australian PICUs started forming in the early 1960s, arising out of postoperative recovery wards with congenital heart surgery. In 1963, Drs. John Stocks and Ian McDonald at the Royal Children's Hospital, Melbourne introduced postoperative mechanical ventilation with prolonged naso-tracheal intubation. Geoffrey Barker was named chief after John Stocks' untimely death in 1974. He was followed by Geoff Mullins from 1976 to 1981, Alan Duncan from 1981-1986, and Frank Shann in 1986. James Tibballs was named the department deputy director in 1983 [108-110]. Other units soon developed in Adelaide, Perth, Sydney, and Brisbane.

At The Children's Hospital of Adelaide, critical care of patients was pioneered by Drs. Tom Allen and Ian Steven (anesthesiologists) in the late 1950s and early 1960s. The patients were first grouped in a single area, the Collingrove Ward in the late 1960s initially under the direction of Dr. Don Sweeney (anesthesia) who trained in Toronto. In 1983, Dr. Neil Matthews, the first full-time pediatric intensive care specialist was named director, and the ward officially became the PICU [111].

An important contribution to the development of intensive care was use of plastic endotracheal tubes for prolonged intubation and ventilation. Dr. Bernard Brandstater, an Australian trained in San Francisco and working at the American Hospital in Beirut, Lebanon, reported prolonged naso-tracheal intubation as an alternative to the tracheostomy at the First European Congress of Anesthesia in 1962 [112]. 
The first full report of prolonged intubation in 50 patients was described in the British Journal of Anesthesia in 1965 by Drs. McDonald and Stocks [113]. At the same time Drs. Allen and Steven of Adelaide were using nasotracheal intubation and tracheostomy in children with severe laryngotracheitis and upper airway obstruction for up to 5 days duration with excellent outcomes. [114]. Australian pediatric critical care is now highly regionalized in tertiary university medical centers supported by sophisticated emergency transport services. Until 1991, all critically ill children in New Zealand received care in a section of an adult ICU (Intensive Care Unit). Matthew Spence, an anesthesiologist, originally from Glasgow, pioneered critical care medicine for adults and children in Auckland, New Zealand, opening the first adult and pediatric ICU in 1958. Ron Trubuhovich as well as others worked in this environment. The first discrete PICU was opened in December, 1991, at the Starship Children's Hospital in Auckland by Dr. Elizabeth Segedin [115,116]. Since 1996, all units have contributed outcome and other data to the Australian and New Zealand Pediatric Intensive Care Registry. The registry has evolved into a multi-center trials research group, affiliated with the Australian and New Zealand Intensive Care Society Clinical Trials Group. Recent evidence utilizing various scoring systems, including the registry-developed PIM (Pediatric Index of Mortality) score, reveals outcomes in the region are better than predicted [117]. A formalized training program evolved during the 1990s, and a separate College of Intensive Care Medicine controls all training in intensive care for the region from 2010 onwards [118-120].

\subsubsection{Europe}

In Europe, pediatric intensive care followed shortly after the poliomyelitis epidemic in Denmark in 1952. As decribed above under The First PICU in 1955, Dr. Goran Haglund, a pediatric anesthesiologist, established the first-medical-surgical PICU for infants and children at the Children's Hospital in Goteberg in Sweden [13]. In 1961 Dr. Hans Feychting, also a pediatric anesthesiologist, established the first PICU at St. Goran's Children's Hospital in Stockholm, Sweden, and became recognized as a pioneer in development of pediatric intensive care in Europe. He introduced many of the skills that had been developed for the operating room and were later applied to pediatric intensive care.
In France, in July 1963, a newborn presented with tetanus and was admitted to l'Hôpital des Enfants Malades of Paris. Shortly afterward, Dr. Gilbert Huault and JB Joly, both neonatologists, opened the first multidisciplinary PICU in France at Saint Vincent de Paul Children's Hospital. This unit was the first pediatrician-directed PICU in Europe; it soon became a major influence on development of PICUs. Drs. Francois Beaufils, Joan Mercier and Denis Devictor were to play an important role in further development of European PCCM [121].

In Britain, a pediatric anesthesiologist, William Glover opened a unit for care of post-operative cardiac patients in 1961 at The Hospital for Sick Children in Great Ormon Street (London). Soon all patients needing ventilator care were admitted to that unit [122] In 1964 a PICU was opened by Dr. G. Jackson Rees, a pediatric anesthesiologist, at the Alder Hey Children's Hospital in Liverpool. Other units soon followed, essentially serving as areas allowing prolonged postoperative support [123].

In Spain, a pediatrician, Dr. Francisco Ruza had started working in neonatal surgical intensive care in 1969. By 1976, he opened a multidisciplinary medicalsurgical PICU for older infants and children at "Hospital Infantil La Paz" in Madrid. This center, directed by Dr. Ruza, has served as a major training center for pediatric intensivists not only from Spain, but from South America as well [124].

The first PICUs in the Netherlands were established in the late 1970s and early 1980s at Rotterdam's Sophia Children's Hospital under Edwin van de Voort (who trained in critical care at CHOP), and Hans van Vught in Rotterdam. PICUs were also developed at, Wilhelmina Children's Hospital in Utrecht, and Emma Children's Hospital at Academic Medical Center in Amsterdam [125]. In 1995, a section on Pediatric Intensive Care Medicine was founded by the Dutch Pediatric Association, which certifies training of nearly all Dutch pediatric intensivists in fellowships programs. These PICUs are multidisciplinary, and all are part of university teaching hospitals. A nationwide transport system connects this centralized care system of pediatric critical care. Dr. Albert Bos in Amsterdam and Dr. van der Voort in Rotterdam continue to foster the highest standards of pediatric critical care. Units were opened in Germany [126] and Slovakia [127] as well as in Krakow, Poland, and many European locations. 


\subsubsection{Israel}

Although located in the Middle East, Israel has traditionally been part of European scientific organizations. The first PICU in Israel was established in 1977 by Dr. Zohar Barzilay as a five-bed facility located within Children's Hospital at Sheba. Now, $35 \mathrm{yr}$ later, Israel has 12 PICUs and two cardiac PICUs. Extracorporeal membrane oxygenation services as well as cardiac transplantation are provided nationwide as part of the national health insurance program. About $30 \%$ of the patients in many of the PICUs in Israel come from the Palestinian Authority. Palestinian physicians trained in PCCM in Israel established the first PICU in Gaza [128,129].

\subsubsection{Latin America}

The first PICU in Latin America was established in Argentina at the Dr. Ricardo Gutierrez Children's Hospital in Buenos Aires in 1969 as part of a general surgery ward. In 1972, Dr. Jorge Sasbon, became first staff director of the PICU. In 1972, a PICU was set up in Pedro de Elizalde Children's Hospital, Buenos Aries, under guidance of Dr. Clara Bonno, and the unit has been a pillar of the specialty in Argentina [18]. With the introduction of international fellowships, Argentinean physicians were able to travel abroad for further training in units in Toronto, Pittsburgh, Madrid, and London. J.P. Garrahan National Pediatric Hospital in Buenos Aires was inaugurated as a teriary center in 1987, and has developed a sophisticated PICU under direction of Dr. Jorge Sasbon.

In Brazil in the 1970s, epidemics of polio and meningococcal disease, with a high mortality, led to creation of small units for care of these patients attended by available personnel. These units were precursors of PICUs later established at Hospital das Clínicas São Paolo by Dr. Anthony Wong (1977), at Hospital São Lucas in Porto Alegre by Dr. Pedro Celiny (1978), and in Rio de Janeiro. At the same time, neonatal intensive care was developing and the model of the NICU was transferred to the care of critically ill children in the 1980s. In 1982, Dr. Jefferson Piva opened a 13-bed PICU at Hospital da Criança Santo Antonio in Porto Alegre [130].

In 1984, the first Brazilian Pediatric Intensive Care Congress in São Paolo took place These congresses continue annually. At the three major tertiary centers in São Paolo, Rio de Janeiro, and Porto Alegre, government agencies actively support research programs. Pediatric intensivists in the Brazilian Pediatric
Society and the Brazilian Critical Care Society worked together to establish the subspecialty, with examination and certification commencing in 1990. Brazil's intensivists also are active in cooperative efforts with other Latin American intensive care societies.

One of the pioneers of development of pediatric critical care in Latin America was Dr. Mauricio Gajer, a dedicated physician from Uruguay. Dr. Gajer, with inspiration and collaboration of Professor Ramon Guerra, created the first PICU in Montevideo, Uruguay in 1975. Dr. Gajer traveled to France, where he worked with Professors Huault and Beaufils. After returning to Uruguay he created the first private PICU in Uruguay. With his enthusiasm to bring all Latin American pediatricians together in the cause of critical care, he organized the first Latin American Pediatric Intensive Care Congress in Uruguay in 1993, which led to development of the Pan American Pediatric Intensive Care Society. In Colombia, Pediatric Intensive Care started in the early 1960s, with postoperative care of cardiovascular patients in Clínica Shaio of Bogotá, with adult cardiologists in charge. Then in the 1970s Dr. Merizalde, a pediatrician with training in pediatric cardiology provided care for pediatric cardiovascular patients. In 2007, the first pediatric critical care training program started in Bogotá, and 2 yr later there were five programs in three cities [131].

In 1956, at Luis Calvo Mackenna Children's Hospital, in Santiago, Chile, a single-bed postoperative care unit was started by Drs. Helmut Jager (cardiac surgeon) and Fernando Eimbecke (cardiology). In 1968 this evolved into a five-bed PICU led by Dr. Eduardo Bancalari, a neonatologist and now a leading perinatologist in the United States. He was later joined by pediatricians Drs. Patricio Olivio and Jaime Cordero. In the 1970s, Dr. Carlos Casar started a PICU at Roberto del Rio Children's Hospital in Santiago, Chile, and then by Dr. Bettina von Dessauer (pediatrician) [132]. There was no formal training in PCCM and these pediatricians devised individual programs to prepare themselves for taking care of critically ill children. Intensivists there have devoted great effort toward developing transport systems to overcome the impact of Chile's challenging geography.

In a similar fashion, the first intensive care unit in San Jose, Costa Rica was opened in 1969 at Hospital Nacional de Niños "Dr. Carlos Sáenz H" as a postoperative cardiac care unit. It was initially a nine-bed unit run by anesthesiologists and surgeons. Eventually 
pediatricians, without special PCCM training, became involved. In 1982 Dr. Aristides Baltodano trained in PICU in Toronto, became the first pediatric intensivist in Costa Rica at Hospital Nacional de Ninos "Dr. Carlos Sáenz H". The hospital now has a 22-bed multidisciplinary unit with more than 1000 admissions per year [133].

\subsubsection{The Developing World}

Replicating demonstrated success elsewhere in India and the developing world will have an immense impact on resources. For example, in India, because of the high birth rates (annual births of 25 million) and large pediatric population (35\% of total or approximately 300 million), the required number of NICU and PICU beds will be enormous. It would therefore be prudent that all District hospitals (750 in the country) be upgraded to provide good level II services to meet the needs of rural communities [134].

Although development of PICUs is essential for overall improvement of child survival in developing countries, the high cost of intensive care limits patients' access to PICU services. A recent study in Paupa New Guinea demonstrated that use of pulse oximetry and supplemental oxygen in addition to clinical signs before initiating antibiotics, according to a World Health Organization (WHO) protocol, decreased mortality by $30 \%$ [135]. Similar low-cost innovative approaches may meet the initial demands for care of the critically ill in the developing world [136]. Several authors have emphasized the need for simple solutions, including access to primary care and preventive measures, to reduce the need for complex care which may not be appropriate in resource poor settings [137-141]. It is therefore important to train health care personnel in early detection of infants and children at high risk of critical disorders such as respiratory failure and prompt intitiation of treatment that might reduce the need for a PICU admission.

In 2007, the SCCM charged eight members to develop a pediatric course similar to Adult Fundamental Critical Care Support (FCCS) course [142]. The first edition of the Pediatric Fundamental Critical Care Support course and textbook (PFCCS) was released by the Society of Critical Care in May 2008 [143]. PFCCS is designed to be a major resource to those interested in learning how to recognize critical illness and initiate care for the critically ill pediatric patient, in the absence of an intensivist. The objectives include: prioritize the immediate needs, select appropriate diagnostic tests, identify and respond to significant changes in vital systems, and determine the need for expert consultation and/or patient transfer. The course focuses on early recognition and management of shock, airway obstruction, respiratory failure, neurologic disease, metabolic and infectious disorders, and trauma, and the need for transport. There are several didactic lectures and multiple clinical stations to allow for hands-on training. The course is accompanied by a 500 page textbook and a pre and post-test for the course. The course is designed to be offered in both a low tech (intubating heads, CPR(Cardiopulmonary resuscitation mannequins) and high tech (simulators) learning locations, depending on available resources. PFCCS has been translated into several languages, and has been offered in 19 countries to date (Argentina, Australia, Belize, Brazil, Cambodia, Chile, Egypt, Haiti, India, Indonesia, Japan, Kenya, Mexico, Nepal, Oman, Qatar, Saudi Arabia and Spain).

\subsection{Recognition of Achievement}

There are many physicians and nurses who have been recognized for their contributions to the field by their peers and organizations. These include the early directors and units (Table 1) and authors of major textbooks (Table 2). In addition, there are many physicians from numerous countries who have helped in major ways to develop and enrich the field of PCCM. Only a few have been recognized for their contributions including the recipients of the international pioneer awards of the WFPICCS (Table 3); and the distinguished career awards of the Section on Critical Care of the AAP (Table 4).

Table 3

International pioneer awards World Federation of Pediatric Intensive Critical Care Societies*

\begin{tabular}{ll}
\hline Name & Country \\
\hline Alan Conn & Canada \\
John Downes & United States \\
Hans Feychting & Sweden \\
Maurico Gajer & Uruguay \\
Gilbert Huault & France \\
Seigo Iwai & Japan \\
Max Klein & South Africa \\
John Stocks & Australia \\
\hline
\end{tabular}

* Awarded Montreal, 2000 
Table 4

Distinguished career awardees, section on critical care, American Academy of Pediatrics

\begin{tabular}{ll}
\hline Years & Name \\
\hline 1995 & David Todres, MD \\
1996 & John Downes, MD \\
1997 & Peter Holbrook, MD \\
1998 & George Gregory, MD \\
1999 & George Lister, MD \\
2000 & Russell Raphaely, MD \\
2001 & Murray Pollack, MD \\
2002 & Daniel Levin, MD \\
2003 & Ann Thompson, MD \\
2004 & Bradley Fuhrman, MD \\
2005 & J. Michael Dean, MD \\
2006 & David Nichols, MD \\
2007 & Ashok Sarnaik, MD \\
2008 & Patrick Kochanek, MD \\
2009 & Jerry Zimmerman, MD \\
2010 & M. Michelle Moss, MD \\
2011 & Timothy Yeh, MD \\
2012 & Niranjan Kissoon, MD \\
2013 & Vinay Nadkarni, MD \\
\hline
\end{tabular}

\section{Acknowledgments}

We would like to thank the following individuals and organizations for their help in preparing this manuscript and getting the dates and facts correct: Aristides Baltonado, Andrew Argent, Geoffrey Barker, John Beca, Jeffrey Burns, Gabriel Cassalett, Edward E. Conway, Jr., Peter Cox, Robert Crone, Martha Curley, J. Michael Dean, Bettina von Dessauer, Denis Devictor, Alan Duncan, Gideon Eshel, Alan Fields, Bradley Fuhrman, George Gregory, David Hatch, Mary Fran Hazinski, Peter Holbrook, Max Klein, Patrick Kochanek, Jacques LaCroix, Jos Latour. George Lister, Niranjan Kissoon, M. Michele Moss, David Nichols, Bradley Peterson, Jefferson Piva, Arnold Platzker, Bala Ramachandran, Adrienne Randolph, Ramana Rao, Mark Rogers, Francisco Ruza, Hirakazu Sakai, David Schell, Gregory Stidham, Ann Thompson, James Thomas, Ron Trubuhovich, Dharmapuri Vidyasagar, Edwin vander Voort, Gary Williams, Doughlas Wilson, Timothy Yeh, the World Federation of Pediatric Intensive and Critical Care Societies, the American Academy of Pediatrics, the Sub-board of the American Board of Pediatrics, the Society of Critical Care Medicine.

The work is supported, in part, by the Susan J. Epply Endowment, Children's Hospital at Dartmouth (DLL).

The authors have not disclosed any potential conflicts of interest.

\section{References}

[1] Todres ID. History of pediatric critical care. In: Fuhrman BP, Zimmerman JJ, editors. Pediatric critical care. 3rd ed. St. Louis: CV Mosby, 2005. p. 7-14.

[2] Downes JJ. Development of pediatric critical care medicine how did we get here and why? In: Wheeler DS, Wong HR, and Shanley TP, editors. Pediatric critical care medicine: basic science and clinical evidence. London: Springer, 2007. p. 3-30.

[3] Bachman L, Downes JJ, Richards CC, Coyle D, May E. Organization and function of an intensive care unit in a children's hospital. Anesth Analg 1967;46(5):570-4.

[4] Levin DL. History of pediatric critical care medicine. In: Fuhrman BP, Zimmerman, JJ editors. Pediatric critical care medicine. 4th ed. Philadelphia: Elsevier, 2011. p. 3-19.

[5] Guidelines for pediatric intensive care units. Crit Care Med 1983;11(9):753-60.

[6] Guidelines and levels of care for pediatric intensive care units. Committee on Hospital Care of the American Academy of Pediatrics and Pediatric Section of the Society of Critical Care Medicine. Pediatrics. 1993;92(1):166-75.

[7] Rosenberg DI, Moss MM. American Academy of Pediatrics Section on Critical Care; American Academy of Pediatrics Committee on Hospital Care. Guidelines and levels of care for pediatric intensive care units. Pediatrics 2007;114(4): 1114-25.

[8] Randolph AG, Gonzales CA, Cortellini L, Yeh TS. Growth of pediatric intensive care units in the United States from 1995 to 2001. J Pediatr 2004;144(6):792-8.

[9] Costarino AT Jr, Downes JJ. Pediatric anesthesia historical perspective. Anesthesiol Clin North America 2005;23(4): 573-95.

[10] Snider GL. Historical perspective on mechanical ventilation: from simple life support system to ethical dilemma. Am Rev Respir Dis 1989;140(2 Pt 2):S2-7.

[11] Downes JJ. Historic origins and role of pediatric anesthesiology in child health care. Pediatr Clin North Am 1994;41(1):1-14.

[12] Downes JJ. The historical evolution, current status, and prospective development of pediatric critical care. Crit Care Clin 1992;8(1):1-22.

[13] Haglund G, Werkmaster K, Ekstrom-Jodal B, McDougall $\mathrm{DH}$. The pediatric emergency ward-principles and practice after 20 years. In: Stetson JB, Swyer PR, editors. Neonatal intensive care. St. Louis: WH Green, 1976. p. 73-87.

[14] Epstein D, Brill JE. A history of pediatric critical care medicine. Pediatr Res 2005;58(5):987-96.

[15] Kampschulte S, Safar P. Development of a multidisciplinary pediatric intensive care unit. Crit Care Med 1973;1(6):308-15.

[16] Berlin CM. The pediatric intensive care unit. Med Ann Dist Columbia 1970;39(9):483-6.

[17] Holbrook P. Address to the section on critical care medicine. 25th anniversary 1984-2009. APP, Washington, DC. October $18,2009$.

[18] Rogers MC. The history of pediatric intensive care around the world. In: Nichols DG, editor. Roger's textbook of pediatric intensive care. Philadelphia: Lippincott Williams and Williams, 2008. p. 3-17.

[19] Philip AG. The evolution of neonatology. Pediatr Res 2005;58(4):799-815.

[20] Noonan JA. A history of pediatric specialties: the development of pediatric cardiology. Pediatr Res 2004;56(2):298-306.

[21] Smythe PM, Bull A. Treatment of tetanus neonatorum with intermittent positive-pressure respiration. Br Med J 1959; 2(5143):107-13. 
[22] Delivonia-Papadopoulos M, Swyer PR. Assisted ventilation in terminal hyaline membrane disease. Arch Dis Child 1964;39:481-4.

[23] Gregory GA, Kitterman JA, Phibbs RH, Tooley WH, Hamilton WK. Treatment of the idiopathic respiratory-distress syndrome with continuous positive airway pressure. N Engl J Med 1971;284(24):1333-40.

[24] Drinker P, McKhann CF. Landmark article May 18, 1929: The use of a new apparatus for the prolonged administration of artificial respiration. I. A fatal case of poliomyelitis. By Philip Drinker and Charles F. McKhann. JAMA 1986;255(11):1473-5.

[25] Drinker PA, McKhann CF 3rd. Landmark perspective: The iron lung. First practical means of respiratory support. JAMA 1986;255(11):1476-80.

[26] Lassen HC. A preliminary report on the 1952 epidemic of poliomyelitis in Copenhagen with special reference to the treatment of acute respiratory insufficiency. Lancet 1953; 1(6749):37-41.

[27] Ibesen B. Treatment of respiratory complications in poliomyelitis; the anesthetist's viewpoint. Dan Med Bull 1954; 1(1):9-12.

[28] Ibsen B. The anaesthetist's viewpoint on the treatment of respiratory complications in poliomyelitis during the epidemic in Copenhagen, 1952. Proc R Soc Med 1954;47(1):72-4.

[29] History of the Multidisciplinary ICU. Johns Hopkins Bayview Medical Center. Available at: http://www.hopkinsbayview. org/icu50th/history/html.

[30] Porter R. The greatest benefit to mankind. New York: WW Norton, 1997. p. 178-461.

[31] Nightingale F. Notes on hospital. 3rd ed. London: Longman, 1963. p. 86

[32] Harrison VC, Heese Hde V, Klein M. The significance of grunting in hyaline membrane disease. Pediatrics 1968;41(3): 549-59.

[33] Max Klein, MD. Personal communication.

[34] Bradley Peterson, MD. Personal communication.

[35] Bradley Fuhrman, MD. Personal communication.

[36] George Lister, MD. Personal communication.

[37] Mark Rogers, MD. Personal communication.

[38] Jones R, Owens-Thomas J, editors. Care of the critically ill child. London: Edward Arnold; 1971.

[39] Roberts K, Edward JM. Paediatric intensive care: a manual for resident medical officers and senior nurses. Oxford: Blackwell; 1971.

[40] Dickerman JD, Lucey JF. Smith's the critically ill child: Diagnosis and medical management. Philadelphia: WB Saunders Co; 1972.

[41] Levin D, Morriss F, Moore G. A practical guide to pediatric intensive care. St. Louis: CV Mosby; 1979.

[42] Levin D, Morriss F. A practical guide to pediatric intensive care. 2nd edition. St. Louis: CV Mosby; 1984.

[43] Levin D, Morriss F, editors. Essentials of pediatric intensive care. St. Louis: Quality Medical Publications; 1990.

[44] Levin D, Morriss F. editors. Essentials of pediatric intensive care, 2nd edition. St. Louis, New York: Quality Medical Publications, Churchill Livingston; 1997.

[45] Ruza FJ. Tratado de ciududos intensivos pediatricas (Textbook of pediatric intensive care). Madrid Editorial NormaCapitel; 1980.

[46] Hazinski MF. Nursing care of the critically ill child. St. Lous: CV Mosby; 1984.

[47] Shoemaker WC, Thompson WL, Holbrook PR, editors. Textbook of critical care. Philadelphia: WB Saunders; 1984.
[48] Nussbaum E. Pediatric intensive care. Mount Kisco, NY: Futura; 1984

[49] Piva JP, Celiny-Garcia P, editors. Temeas em terapia intensiva pediatrica (Critical care in pediatrics). Brazil: Sociedade Brasileira de Pediatria; 1985.

[50] Zimmerman SS, Gildea JH, editors. Critical care pediatrics. Philadelphia: WB Saunders; 1985.

[51] Morray JP. Pediatric intensive care. Norwalk: Conn, Appleton \& Lange; 1987.

[52] Rogers MC. Textbook of pediatric intensive care. Philadelphia: Williams \& Wilkins; 1988.

[53] Fuhrman, BP, Zimmerman JJ, editors. Pediatric critical care. St. Louis: Mosby Year Book; 1992.

[54] Holbrook PR. Textbook of pediatric critical care. Philadelphia: WB Saunders; 1993.

[55] Lacroix J, Gauthier M, Beaufils F, editors. Urgences et sions intensifs pediatriques (Pediatric emergency and critical care). Montreal \& Paris: Les Presses de Universite de Montreal \& Dion; 1994.

[56] Nichols DG, Cameron DE, Greeley WJ, Lappe DG, Ungerleider RM, Wetzel RC, editors. Critical heart disease in infants and children. St. Louis: Mosby; 1995.

[57] Todres ID, Fugate JH, editors. Critical care of infants and children. Boston: Little, Brown \& Co; 1996.

[58] Curley MAQ, Bloedel-Smith J, Moloney-Harmon PA, editors. Critical care nursing of infants and children. Philadelphia: WB Saunders; 1996.

[59] Dieckmann, RA, Fiser DH, Selbst SM, editors. Pediatric emergency and critical care procedures. St. Louis: Mosby; 1997.

[60] Morton NS. Paediatric intensive care. Oxford: Oxford University Press; 1997.

[61] Lopez-Herce Cid J, Lorente Acosta MJ, Baltodano Aguero A, editors. Manual de cuidados intensivos pediatricos. Madrid: Publimed; 2001.

[62] Forero G, Alarcon J, Cassalett B, editors. Cuidado intensivo pediatrico y neonatal. (Please write the place of publication): Editorial Distribuna; 2005.

[63] Slonim AD, Pollack MM, editors. Pediatric critical care medicine. Philadelphia: Lippincott, Williams and Wilkins; 2006.

[64] Wheeler DS, Wong HR, Shanley TP, editors. Pediatric critical care medicine: basic science and clinical evidence. London: Springer; 2007.

[65] Calvin JE, Habet K, Parrillo JE. Critical care in the United States. Who are we and how did we get here? Crit Care Clin 1997;13(2):363-76.

[66] Lister G. Pediatric critical care medicine. In: Pearson HA, editor. American Board of Pediatrics 1933-2008. Chapel Hill, NC, American Board of Pediatrics; 2008. p. 168-172.

[67] Pediatric critical care medicine. Clin Privil White Pap 2007; (414):1-16

[68] Althouse LA, Stockman JA 3rd. Pediatric workforce: a look at pediatric critical care medicine data from the American Board of Pediatrics. J Pediatr 2006;149(3):390-92.

[69] Timothy Yeh. Ross Planning Associates. Pediatric Intensive Care Questionnaire 1979. Personal Communication.

[70] Patrick Kochanek, MD. Personal Communication.

[71] Davies MW, Sargent PH. Partial liquid ventilation for the prevention of mortality and morbidity in paediatric acute lung injury and acute respiratorydistress syndrome. Cochrane Database Syst Rev 2004;(2):CD003845.

[72] Fuhrman BP, Paczan PR, DeFrancisis M. Perfluorocarbonassociated gas exchange. Crit Care Med 1991;19(5):712-22. 
[73] Levin M, Quint PA, Goldstein B, Barton P, Bradley JS, Shemie $\mathrm{SD}$, et al. Recombinant bactericidal/permeability-increasing protein (rBPI21) as adjunctive treatment for children with severe meningococcal sepsis: a randomised trial. rBPI21 Meningococcal Sepsis Study Group. Lancet 2000;356(9234):961-7.

[74] Giroir BP. Recombinant human activated protein C for the treatment of severesepsis: is there a role in pediatrics? Curr Opin Pediatr 2003;15(1):92-6.

[75] Gregory Stidham, MD. Personal Communication.

[76] Randolph AG, Wypij D, Venkataraman ST, Hanson JH, Gedeit RG, Meert KL, et al.; Pediatric Acute Lung Injury and Sepsis Investigators (PALISI) Network. Effect of mechanical ventilator weaning protocols on respiratory outcomes in infants and children: a randomized controlled trial. JAMA 2002;288(20):2561-8.

[77] Lacroix J, Hébert PC, Hutchison JS, Hume HA, Tucci M, Ducruet T, e; TRIPICU Investigators; Canadian Critical Care Trials Group; Pediatric Acute Lung Injury and Sepsis Investigators Network. Transfusion strategies for patients inpediatric intensive care units. N Engl J Med 2007;356(16):1609-19.

[78] Willson DF, Thomas NJ, Markovitz BP, Bauman LA, DiCarlo JV, Pon S, et al.; Pediatric Acute Lung Injury and Sepsis Investigators. Effect of exogenous surfactant (calfactant) in pediatric acute lung injury: a randomized controlled trial. JAMA 2005;293(4):470-6.

[79] Fineman LD, LaBrecque MA, Shih MC, Curley MA. Prone positioning can be safely performed in critically ill infants and children. Pediatr Crit Care Med 2006;7(5):413-22.

[80] Marshall JC, Cook DJ; Canadian Critical Care Trials Group. Investigator-led clinical research consortia: the Canadian Critical Care Trials Group. Crit Care Med 2009;37(1 Suppl):S165-72.

[81] Adrienne Randolph, MD. Personal Communication.

[82] Jacques LaCroix, MD. Personal Communication.

[83] Douglas Willson, MD. Personal Communication.

[84] J. Michael Dean, MD. Personal Communication.

[85] DuPont HL, Spink WW. Infections due to gram-negative organisms: an analysis of 860 patients with bacteremia at the University of Minnesota Medical Center,1958-1966. Medicine (Baltimore) 1969;48(4):307-32.

[86] Pollack MM, Cuerdon TT, Patel KM, Ruttimann UE, Getson PR, Levetown M. Impact of quality-of-care factors on pediatric intensive care unit mortality. JAMA 1994;272(12):941-6.

[87] Tilford JM, Roberson PK, Lensing S, Fiser DH. Differences in pediatric ICU mortality risk over time. Crit Care Med 1998;26(10):1737-43.

[88] Yeh TS. Regionalization of pediatric critical care. Crit Care Clin 1992;8(1):23-35.

[89] Orr RA, Felmet KA, Han Y, McCloskey KA, Dragotta MA, Bills DM, et al. Pediatric specialized transport teams are associated with improved outcomes. Pediatrics 2009;124(1): 40-8.

[90] McPherson ML, Graf JM. Speed isn't everything in pediatric medical transport. Pediatrics 2009;124(1):381-3.

[91] Chalom R, Raphaely RC, Costarino AT Jr. Hospital costs of pediatric intensive care. Crit Care Med 1999;27(10):2079-85.

[92] Downes JJ, Parra MM. Costs and reimbursement issues in long term mechanical ventilation. In: Hill NS. Long term mechanical ventilation. New York: Marcel Decker, 2001; p. 353-374.

[93] Martinez M. Psychosocial aspects of pediatric intensive care: The parent. In: Levin DL, Morriss FC, editors. Essentials of pediatric intensive care medicine. 2nd ed. St. Louis: Quality Medical Publisher and New York, Churchill Livingstone, 1997. p. $1035-1038$.
[94] Jarvis JD, Levin D. Joint discussion making in rounds in the PICU results in positive outcomes and improved satisfaction. Oral Abstract. Presented at the AAP NCE, Section on Critical Care. Washington, DC, Oct 2005.

[95] Kochanek PM. Pediatric Critical Care Medicine, our expanding global mission. Pediatr Crit Care Med 2001;2(2):106-7.

[96] Geoffrey Barker, MD. Personal Communication.

[97] Andrew Argent, MD. Personal Communication.

[98] Hirokazu Sakai, MD. Personal Communication.

[99] Vidyasagar D, Singh M, Bhakoo ON, Paul VK, Narang A, Bhutani V, et al. Evolution of neonatal and pediatric critical care in India. Crit Care Clin 1997;13(2):331-46.

[100] Nangia S, Saili A, Dutta AK, Gaur V, Singh M, Seth A, Kumari S. Neonatal mechanical ventilation-experience at a level II care centre. Indian J Pediatr 1998;65(2):291-6.

[101] Govil YC. Pediatric intensive care in India: time for introspection and intensification. Indian Pediatr 2006;43(8):675-8.

[102] http://www.isccm.org/issm/Aboutpediatric.aspx.

[103] www.wfpiccs.prg/docs/news/pccc_india_wfpiccs_website.pdf.

[104] Khilnani P; Indian Society of Critical Care Medicine (Pediatric Section); Indian Academy of Pediatrics (Intensive care chapter). Consensus guidelines for pediatric intensive care units in India. Indian Pediatr 2002;39(1):43-50.

[105] Ranganath D, Sita Rama Rao B, Beligere N, Vidyasagar D. Under five mortality in PICU serving urban and rural population in India. Presented at Ped Academic Societies Meeting. Toronto, Canada, 2007.

[106] GVK Emergency Manaement and Research Institute. Available at: http://www.emri.in.

[107] Dr. Ramana Rao. EMRI. Personal Communication.

[108] Yule P. The second floor. Anesthesia, intensive care, neonatology and the operating suite, in the history of The Royal Children's Hospital: a history of faith, science and love. New South Wales: Halstead Press Pub; 1999.

[109] Webb D, Warren D. Intensive care unit, "A new deal for "little adults" in safe in our hands". Pub Western Australia: 100 years of Princess Margaret Hospital for Children Foundation, Inc; 2009.

[110] Alan Duncan, MD. Personal Communication.

[111] Neil Matthews, MD. Personal Communication.

[112] Brandstater B. Prolonged intubation an alternative to tracheostomy in infant procedures. First European Congress of Anesthesiology. 1962.

[113] McDonald IH, Stocks JG. Prolonged nasotracheal intubation. A review of its development in a paediatric hospital. $\mathrm{Br}$ J Anaesth 1965;37:161-73.

[114] Allen TH, Steven IM. Prolonged endotracheal intubation in infants and children. Br J Anaesth 1965;37(8):566-73.

[115] John Beca, MD. Personal Communication.

[116] Ron Trubuhovich, MD. Personal Communication.

[117] Shann F, Pearson G, Slater A, Wilkinson K. Paediatric index of mortality (PIM): a mortality prediction model for children in intensive care. Intensive Care Med 1997;23(2):201-7.

[118] College of Intensive Care Medicine of Australia and New Zealand. http://cicm.org.au.

[119] David Schell, MD. Personal Communication.

[120] Gary Williams, MD. Personal Communication.

[121] Denis Devictor, MD. Personal Communication.

[122] David Hatch, MD. Personal Communication.

[123] Sinclair J. The spectrum of paediatric intensive care. In: Pediatric intensive care. Oxford: Oxford University Press; 1997

[124] Francisco Ruza, MD. Personal Communication.

[125] Edwin van der Voort, MD. Personal Communication. 
[126] Prien T, Meyer J, Lawin P. Development of intensive care medicine in Germany. J Clin Anesth 1991;3(3):253-8.

[127] Benedekova M. Children in the focus of the attention of pediatricians and pediatric surgeons. Bratisl Lek Listy 2003; 104(9):255-8.

[128] Amir Vardi, MD. Personal Communication.

[129] Gideon Eshel, MD. Personal Communication.

[130] Jefferson Piva, MD. Personal Communication.

[131] Gabriel Cassalett, MD. Personal Communication.

[132] Bettina von Dessauer, MD. Personal Communication.

[133] Aristides Baltodano, MD. Personal Communication.

[134] Khilnani P, Sarma D, Singh R, Uttam R, Rajdev S, Makkar A, Kaur J. Demographic profile and outcome analysis of a tertiary level pediatric intensive care unit. Indian J Pediatr 2004;71(7): 587-91.

[135] Duke T, Mgone J, Frank D. Hypoxaemia in children with severe pneumonia in Papua New Guinea. Int J Tuberc Lung Dis 2001;5(6):511-9.

[136] Maitland K, Kiguli S, Opoka RO, Engoru C, Olupot-Olupot $\mathrm{P}$, Akech SO, et al.; FEAST Trial Group. Mortality after fluid bolus in African children with severe infection. N Engl J Med 2011;364(26):2483-95.

[137] Molyneux E, Ahmad S, Robertson A. Improved triage and emergency care for children reduces inpatient mortality in a resource-constrained setting. Bull World Health Organ 2006; 84(4):314-9.

[138] Bhutta ZA, Ali S, Cousens S, Ali TM, Haider BA, Rizvi A, et al. Alma-Ata: Rebirth and Revision 6 Interventions to address maternal, newborn, and child survival: what difference can integrated primary health care strategies make? Lancet 2008;372(9642):972-89.

[139] Baker T. Pediatric emergency and critical care in low-income countries. Paediatr Anaesth 2009;19(1):23-7.

[140] Kissoon N. Out of Africa-a mother's journey. Pediatr Crit Care Med 2011;12(1):73-9.

[141] Shann F. Role of intensive care in countries with a high child mortality rate. Pediatr Crit Care Med 2011;12(1): 114-5.

[142] Edward E. Conway, Jr., Personal Communication.

[143] Society of Critical Care Medicine: Pediatric Fundamental Critical Care Support. 2008. 